\title{
Indications for algae-degrading benthic microbial communities in deep-sea sediments along the Antarctic Polar Front
}

\author{
S. Emil Ruff ${ }^{\mathrm{a}, \mathrm{b}}$, David Probandt ${ }^{\mathrm{a}}$, Ann-Christine Zinkann ${ }^{\mathrm{c}}$, Morten H. Iversen ${ }^{\mathrm{d}, \mathrm{e}, \mathrm{f}}$, \\ Christine Klaas $^{\mathrm{f}}$, Laura Würzberg ${ }^{\mathrm{c}}$, Nicole Krombholz ${ }^{\mathrm{a}}$, Dieter Wolf-Gladrow ${ }^{\mathrm{f}}$, \\ Rudolf Amann ${ }^{a}$, Katrin Knittel ${ }^{\mathrm{a}, *}$ \\ ${ }^{a}$ Department of Molecular Ecology, Max Planck Institute for Marine Microbiology, Celsiusstrasse 1, 28359 Bremen, Germany \\ ${ }^{\mathrm{b}}$ HGF-MPG Group for Deep-Sea Ecology and Technology, Max Planck Institute for Marine Microbiology, Celsiusstrasse 1, 28359 Bremen, Germany \\ ${ }^{\mathrm{c}}$ Biocentre Grindel and Zoological Museum, University of Hamburg, Martin-Luther-King-Platz 3, 20146 Hamburg, Germany \\ d Center for Marine Environmental Sciences (MARUM), University of Bremen, Klagenfurterstrasse, 28334 Bremen, Germany \\ e Department of Geosciences, University of Bremen, Klagenfurterstrasse, 28334 Bremen, Germany \\ ${ }^{\mathrm{f}}$ Alfred Wegener Institute for Polar and Marine Research, Am Handelshafen 12, 27570 Bremerhaven, Germany
}

\section{A R T I C L E I N F O}

Available online 4 June 2014

\section{Keywords:}

Southern Atlantic Ocean

Benthic-pelagic coupling

Microbial community structure

Abyssal

Bacterial diversity

Flavobacteria

NOR5/OM60

Particulate organic carbon

\begin{abstract}
A B S T R A C T
Phytoplankton blooms in surface waters of the oceans are known to influence the food web and impact microbial as well as zooplankton communities. Numerous studies have investigated the fate of phytoplankton-derived organic matter in surface waters and shelf sediments, however, little is known about the effect of sinking algal biomass on microbial communities in deep-sea sediments. Here, we analyzed sediments of four regions in the Southern Atlantic Ocean along the Antarctic Polar Front that had different exposures to phytoplankton bloom derived organic matter. We investigated the microbial communities in these sediments using high-throughput sequencing of 16S rRNA molecules to determine microorganisms that were active and catalyzed reporter deposition fluorescence in situ hybridization to infer their abundance and distribution. The sediments along the Antarctic Polar Front harbored microbial communities that were highly diverse and contained microbial clades that seem to preferably occur in regions of high primary productivity. We showed that organisms affiliated with the gammaproteobacterial clade NOR5/OM60, which is known from surface waters and coastal sediments, thrive in the deepsea. Benthic deep-sea NOR5 were abundant, diverse, distinct from pelagic NOR5 and likely specialized on the degradation of phytoplankton-derived organic matter, occupying a similar niche as their pelagic relatives. Algal detritus seemed to not only fuel the benthic microbial communities of large areas in the deep-sea, but also to influence communities locally, as we found a peak in Flavobacteriaceae-related clades that also include degraders of algal biomass. The results strongly suggest that phytoplanktonderived organic matter was rapidly exported to the deep-sea, nourished distinct benthic microbial communities and seemed to be the main energy source for microbial life in the seafloor of vast abyssal regions along the Antarctic Polar Front.
\end{abstract}

(c) 2014 Elsevier Ltd. All rights reserved.

\section{Introduction}

The extent of primary productivity and the availability of organic matter greatly influence the structure of heterotrophic communities in the oceans, including both macrofauna (Levin and Gage, 1998) and microorganisms (Horner-Devine et al., 2003). Phytoplankton blooms in the euphotic zone of the oceans serve as a food source for zooplankton (Löder et al., 2011) and pelagic

\footnotetext{
* Corresponding author.

E-mail address: kknittel@mpi-bremen.de (K. Knittel).
}

communities (Pinhassi et al., 2004; Teeling et al., 2012). These blooms can shift entire planktonic microbial communities from being dominated by oligotrophic Alphaproteobacteria to being dominated by copiotrophic Flavobacteria that grow on decaying algae and Gammaproteobacteria that profit from products released by the degradation of algal biomass (Teeling et al., 2012). Some genera of Flavobacteria, such as Polaribacter, Formosa and Ulvibacter, are known to specialize on the degradation of complex polysaccharides that are characteristic for diatoms, such as laminarin, fucan and sulfated polysaccharides in the cell wall. They access these large molecules through specific transport systems, carbohydrate-active enzymes, including glycoside hydrolases and 
sulfatases, which are typically encoded in so-called polysaccharide utilization loci (Mann et al., 2013; Teeling et al., 2012).

Although most of the bloom biomass is remineralized in the food web of the euphotic zone, some of the organic matter escapes degradation in the surface waters and is exported to the mesoand bathypelagial. Estimates on the amount of exported biomass range from around 2\% (Fischer et al., 2000) to up to 50\% (Smetacek et al., 2012), while only less than $2 \%$ of the primary produced organic carbon might actually reach the seafloor (Schlüter et al., 2000). Due to permanent darkness most of the life in the abyssal seafloor is dependent on this input of photosynthesisderived particulate organic carbon (POC) from the ocean surface (Jørgensen and Boetius, 2007; Sevastou et al., 2013). It was shown that settled POC is taken up by meio- and macrofaunal benthic communities as well as further utilized by microorganisms (Moodley et al., 2002; Witte et al., 2003). POC mainly occurs as algal detritus and fecal pellets (Boyd and Trull, 2007) that have varying sinking speeds between $35 \mathrm{~m} \mathrm{day}^{-1}$ for copepod fecal pellets (Ploug et al., 2008), to around $200 \mathrm{~m}$ day $^{-1}$ for aggregated diatoms (Scharek et al., 1999), to above $2000 \mathrm{~m} \mathrm{day}^{-1}$ for salp fecal pellets (Bruland and Silver, 1981). Regional studies provided evidence that the size-structure of the phytoplankton community, rather than primary productivity, may be the dominant control on the flux of organic matter to the deep sea (Boyd and Newton, 1995, 1999).

Fischer et al. (2000) proposed that in the Southern Ocean, in particular in the Polar Front area, the organic matter produced during phytoplankton blooms might be more rapidly transported downward due to the formation of large particles or mass sedimentation of diatoms. The standing stocks of benthic meioand macrofaunal assemblages of the Southern Ocean further suggest a relatively high supply of POC to the sediments (Brandt et al., 2007). Interestingly, in the Southern Ocean, benthic communities of regions with high surface water productivity were found to be similar to those in low productivity regions (Jamieson et al., 2013) and in sediments below the Ross ice-shelf (Carr et al., 2013), indicating that other factors than just the extent of primary productivity play a role. However, as research focused on macrofaunal benthic communities, little is known about microbial communities in sediments along the Antarctic Polar Front. Thus, it is still unclear whether phytodetritus pulses might also induce rapid shifts in microbial community structure, activity or biomass and whether certain microbial groups benefit more from this input than others on a long term.

Here, we analyzed the bacterial community structure of four abyssal sediments and one shallow reference site in the Atlantic sector of the Southern Ocean using high-throughput sequencing and fluorescence in situ hybridization. The sediments originated from regions that had different exposures to phytoplankton blooms in order to investigate potential links between the blooms and benthic microorganisms. Our main hypotheses were (i) that the seafloor of this region harbors specific bacterial clades that benefit from the sinking algal-derived matter and (ii) that an extended bloom situation in the surface ocean leads to changes in the benthic microbial communities with short delay times.

\section{Materials and methods}

\subsection{Sampling procedure and sampling sites}

The five investigated stations were located along the Antarctic Polar Front between South Africa and Argentina (Fig. 1 and Table 1), of which four stations were abyssal, open ocean sites. Station 81 was sampled around 20 days after the peak of a short phytoplankton bloom (bloom A, duration $\sim 30$ days). This station was likely exposed to low amounts of bloom-derived particulate organic carbon (POC, Table 1 ) and is referred to as A81 short ( bloom A; 81: sampling station 81 ; short: short exposure time to bloom-derived POC). Station 86 was sampled around 10 days after the peak of an extended bloom (bloom B) and was thus also shortly exposed to POC (sample ID: B86 $6_{\text {short }}$ ). Station 141 (sample ID: B141 long) was sampled around 30 days after the peak of the same extended bloom B and had a long exposure to bloomderived POC. Both stations, 86 and 141, were located in the same area, were influenced by the same bloom and seemed to have a similar biogeochemistry. They mainly differed in the time they were exposed to sinking particles. Station 175 (sample ID: C175 long) was sampled 50 days after the peak of another extended bloom (bloom C). The fifth station (sample ID: R177), taken as a reference, was shallow and located on the South American shelf. The samples were retrieved by multi-coring during cruise ANT-XVIII/3 on the German research vessel "FS Polarstern" in 2012. After retrieval, the cores were transferred to the cold room $\left(4{ }^{\circ} \mathrm{C}\right)$ and sectioned at intervals of $1 \mathrm{~cm}$. For the microbial community analysis, we selected four layers (layer 1 : 0-1 cm; layer 2: $1-2 \mathrm{~cm}$; layer 3: $2-3 \mathrm{~cm}$; layer $4: 3-5 \mathrm{~cm}$ ) of each core. Subsamples for nucleic acid extraction were frozen at $-20{ }^{\circ} \mathrm{C}$ and subsamples for CARD-FISH were fixed in $3 \%$ formaldehyde in sterile sea water for a maximum of $8 \mathrm{~h}$ at $4{ }^{\circ} \mathrm{C}$, washed twice with $1 \times$ PBS and stored in $1 \times \mathrm{PBS} /$ absolute ethanol $(1: 1)$ at $-20^{\circ} \mathrm{C}$.

Settling particles were collected using free-drifting sediment traps (referred to as 'drifting traps') at all open-ocean stations. The drifting traps consisted of a drifting array attached to a surface buoy equipped with a GPS satellite transmitter, two surface floats and 12 small buoyancy balls serving as wave breakers to reduce the hydrodynamic effects on the traps. One gimbal mounted collection cylinder $(100 \times 10.4 \mathrm{~cm})$, was deployed at $300 \mathrm{~m}$. The collection cylinder was equipped with $200 \mathrm{ml}$ of a viscous gel (Tissue-Tek $^{\mathbb{R}}$, O.C.T. $^{\text {TM }}$ COMPOUND, Sakura) to intercept and preserve settling particles without destroying their original size and structure. Upon recovery, the particles settled for $12 \mathrm{~h}$ before the gels were removed and photographed using a stereomicroscope.

\subsection{Chlorophyll a measurements}

Water samples for Chlorophyll a (Chla) analysis were collected from Niskin bottles mounted on a CTD rosette and filtered onto $25 \mathrm{~mm}$ diameter GF/F filters at pressures not exceeding 200 mbar. Filters were immediately transferred to centrifuge tubes with $10 \mathrm{ml} 90 \%$ acetone and $1 \mathrm{~cm}^{3}$ of glass beads. The tubes were sealed and stored at $-20{ }^{\circ} \mathrm{C}$ for at least $30 \mathrm{~min}$ and up to $24 \mathrm{~h}$. Chla was extracted by placing the centrifuge tubes in a grinder for $3 \mathrm{~min}$ followed by centrifugation at $0{ }^{\circ} \mathrm{C}$. The supernatant was poured in quartz tubes and measured for Chla content in a Turner 10-AU fluorometer. Calibration of the fluorometer was carried out at the beginning and at the end of the cruise. Results of the fluorometer calibration diverged by $2 \%$ between beginning and end of the cruise. Chla content was calculated as described previously (Knap et al., 1996) using average parameter values from the two calibrations.

\subsection{Particulate organic carbon (POC) measurements}

Water samples for POC analyses were obtained from Niskin bottles attached to a Conductivity Temperature Depth (CTD) rosette from discrete depths between 10 and $150 \mathrm{~m}$ depth at each station. Samples (from 1 to 21 ) were filtered onto pre-combusted glass fiber filters (Whatman GF/F) and stored in pre-combusted glass petri dishes. After filtration filters were dried overnight at 


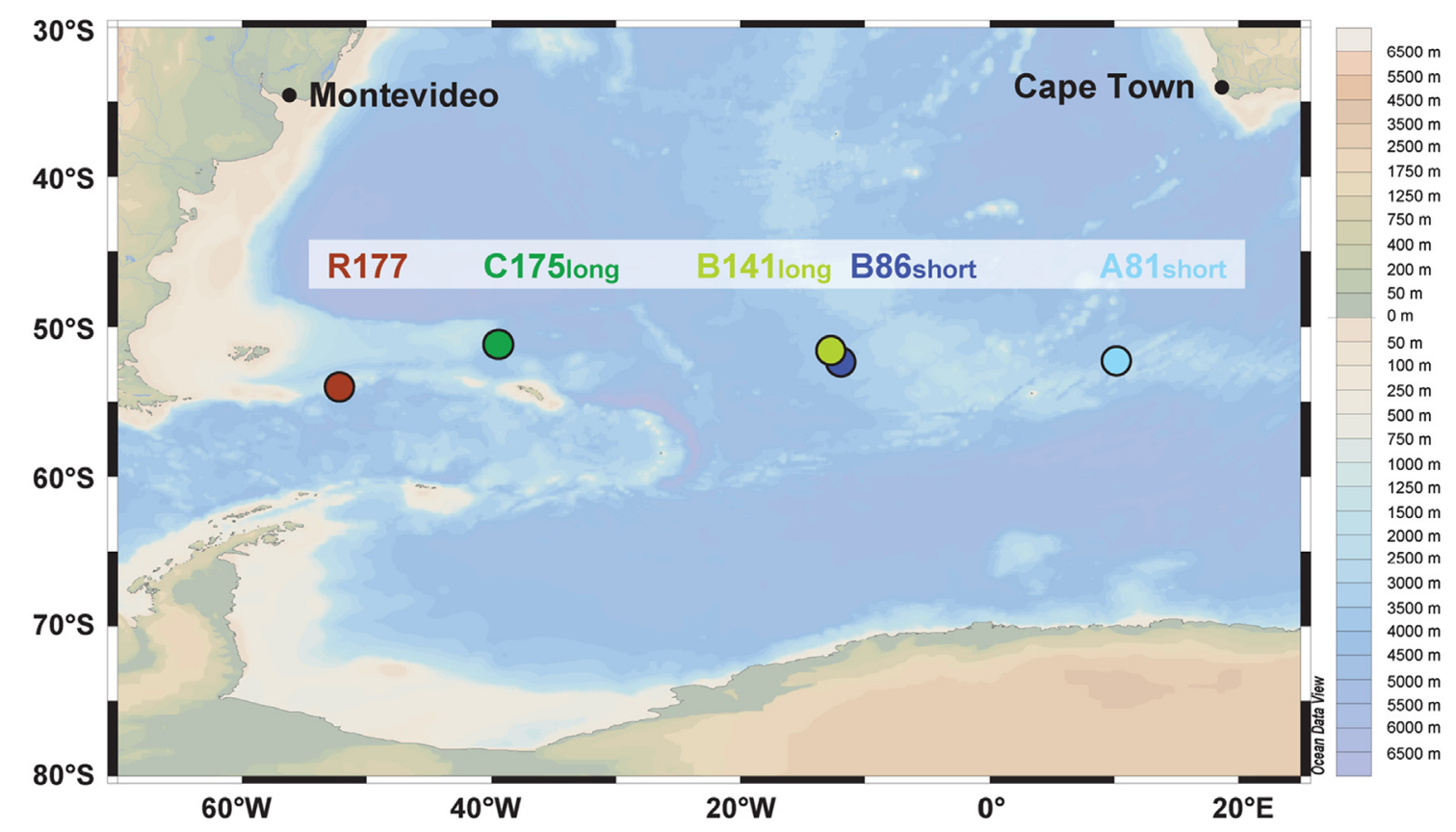

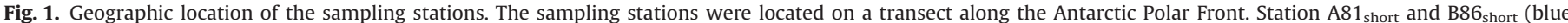

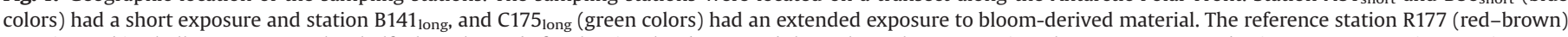

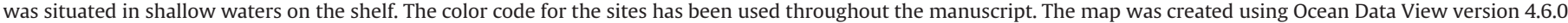
(odv.awi.de).

Table 1

Study sites.

\begin{tabular}{|c|c|c|c|c|c|c|c|c|c|c|c|}
\hline Station & $\begin{array}{r}\text { Sample } \\
\text { ID }\end{array}$ & $\begin{array}{r}\text { Sampling } \\
\text { date }\end{array}$ & Lat. & Long. & $\begin{array}{l}\text { Water } \\
\text { depth }\end{array}$ & $\begin{array}{r}\text { Bloom } \\
\text { ID }\end{array}$ & $\begin{array}{r}\text { Bloom } \\
\text { duration }^{\text {a }}\end{array}$ & $\begin{array}{r}\text { Time after } \\
\text { bloom }\end{array}$ & $\begin{array}{r}\text { Max } \\
\text { Chla }\end{array}$ & Chla $^{\mathrm{b}}$ & Integr. POC ${ }^{\mathrm{b}}$ \\
\hline & & & ${ }^{\circ} \mathrm{S}$ & ${ }^{\circ} \mathrm{E}$ & $\mathrm{m}$ & & $\mathrm{d}$ & $\mathrm{d}$ & {$\left[\mathrm{mg} \mathrm{m}^{-3}\right]$} & $\begin{array}{r}0-100 \mathrm{~m} \\
\text { depth } \\
{\left[\mu \mathrm{g} \mathrm{l}^{-1}\right]}\end{array}$ & $\begin{array}{r}0-150 \mathrm{~m} \\
\text { depth } \\
{\left[\mathrm{g} \mathrm{m}^{-2}\right]}\end{array}$ \\
\hline PS79/081-8 & A81 $1_{\text {short }}$ & $1 / 19 / 2012$ & 52,011 & 10,011 & 3760 & A & $\sim 30$ & 20 & $2-3$ & 0.58 & 10.0 \\
\hline PS79/086-28 & B86 & $2 / 1 / 2012$ & 51,987 & $-12,036$ & 3969 & B & $\sim 100$ & 10 & $\sim 3$ & 2.58 & 31.5 \\
\hline PS79/141-9 & B141 long & $2 / 19 / 2012$ & 51,268 & $-12,618$ & 4114 & B & $\sim 100$ & 30 & $\sim 3$ & 1.55 & 25.4 \\
\hline PS79/175-7 & C175 long & $3 / 4 / 2012$ & 50,784 & $-39,428$ & 4154 & $\mathrm{C}$ & $\sim 100$ & 50 & $>4$ & 0.67 & 13.2 \\
\hline PS79/177-3 & R177 & $3 / 7 / 2012$ & 53,815 & $-52,358$ & 340 & - & - & - & $\max .5$ & n.a. & n.a. \\
\hline
\end{tabular}

n.a.: not analyzed.

POC: particulate organic carbon.

a Determined using MODIS satellite data.

${ }^{\mathrm{b}}$ On sampling day.

$50{ }^{\circ} \mathrm{C}$ and stored frozen $\left(-20^{\circ} \mathrm{C}\right)$ for further analysis on land. POC was measured by gas chromatography with a CHN analyzer (EURO EA Elemental Analyser). Before measurement the filters were treated with $0.1 \mathrm{~N} \mathrm{HCl}$ to remove inorganic carbonate.

\subsection{RNA extraction}

Total nucleic acids were extracted from $1.5 \mathrm{~g}(0-1 \mathrm{~cm}$ depth layer) and $3 \mathrm{~g}(1-2 \mathrm{~cm})$ of sediments as described previously (Stahl et al., 1988), with the following modifications: the physical disruption was carried out with a mixture of $0.4-0.6 \mathrm{~mm}$ glass beads and $0.1 \mathrm{~mm}$ zirconium beads (1:4). Cells were disrupted by bead beating in $4.175 \mathrm{ml}$ lysis solution $(1.5 \mathrm{ml}$ buffer $(50 \mathrm{mM}$ sodium acetate; $10 \mathrm{mM}$ EDTA buffer ( $\mathrm{pH} 5.1)$ ); $2.5 \mathrm{ml}$ phenol (pH 4.5); $175 \mu \mathrm{l} 20 \% \mathrm{SDS}$ ) for two times $45 \mathrm{~s}$ at $6.5 \mathrm{~ms}^{-1}$ (Fastprep24, MPBio). Total nucleic acids were precipitated over night at $-20{ }^{\circ} \mathrm{C}$ with ammonium acetate (3.75 M final concentration) and two volumes isopropanol. The precipitate was washed with $80 \%$ ethanol and resuspended in $150 \mu$ LEPC-treated water. DNA was removed by DNaseI ( $5 \mathrm{U} / \mu \mathrm{l}$, EpiCentre) digestion according to the manufacturer's recommendations. RNA was purified with the RNeasy MiniKit (Qiagen) and eluted in $30 \mu \mathrm{l}$ RNase-free water. No contamination with genomic DNA could be observed as PCRs with the RNA extract as template and the general primers GM3/ GM4 (Muyzer et al., 1995) targeting the bacterial 16S rRNA gene were negative.

\section{5. cDNA synthesis and massively parallel tag sequencing}

Complementary DNA (cDNA) was synthesized from the RNA extract using $25 \mathrm{ng} / \mu \mathrm{l}$ random hexamer primers, $4 \mathrm{U} / \mu \mathrm{l} \mathrm{M}-\mathrm{MLV}$ Reverse Transcriptase RNase $\mathrm{H}$ Minus and $2 \mathrm{U} / \mu \mathrm{l}$ RNasin Plus RNase Inhibitor (Promega) as previously described (Meyerdierks et al., 2010). Bacterial 16S rRNA was amplified from the cDNA templates by PCR using the primers GM3/907R (Muyzer et al., 1995). Modification of the primers was as follows: 907R was barcoded; both primers were extended at the $5^{\prime}$ end with a Sil restriction site for ligation with the 454 adapters. For each sample, 
five replicate PCRs ( $20 \mu$ l volume) were carried out containing, $0.5 \mu \mathrm{M}$ primer each, $250 \mu \mathrm{M}$ dNTPs, $0.3 \mu \mathrm{g} / \mu \mathrm{l}$ BSA, $1 \times$ PCR buffer, 0.25 U Taq DNA Polymerase (5Prime, Germany) under the following conditions: an initial denaturation at $95{ }^{\circ} \mathrm{C}$ for $5 \mathrm{~min}$, followed by 35 cycles of denaturation $\left(95^{\circ} \mathrm{C}, 1 \mathrm{~min}\right)$, annealing $\left(48^{\circ} \mathrm{C}\right.$, $1.5 \mathrm{~min})$, elongation $\left(72{ }^{\circ} \mathrm{C}, 3 \mathrm{~min}\right)$, and a final elongation step $\left(72{ }^{\circ} \mathrm{C}, 10 \mathrm{~min}\right)$. The replicate PCRs were pooled, PCR amplicons extracted from an agarose gel and purified using the MiniElute PCR Purification Kit (Qiagen) according to the manufacturer's recommendations. Massive parallel tag sequencing of the amplicons was carried out on a 454 Life Sciences GS FLX sequencer (Roche, Basel, Switzerland) at the Sequencing Research Center, Cologne, Germany. The sequence reads were submitted to a rigorous quality control procedure using a mothur version 24 routine (Schloss et al., 2009) including trimming, quality filtering of the reads and a chimera check using uchime (Edgar et al., 2011). The reads were taxonomically assigned according to the ARB SILVA taxonomy (Quast et al., 2013) implemented in mothur and clustered at $98 \%$ ribosomal RNA sequence identity.

\subsection{Analyses of community diversity}

Sequence abundance tables that were obtained after the taxonomic assignment were used to calculate inverse Simpson diversity indices, Chao1 richness (Chao, 1984) and species rarefaction with mother based on random subsampling of 2000 sequences per sample. Bray-Curtis dissimilarities (Bray and Curtis, 1957) between all samples were calculated and used for two-dimensional nonmetric multidimensional scaling (NMDS) ordinations with 20 random starts (Kruskal, 1964). Stress values below 0.2 indicated that the multidimensional dataset was well represented by the $2 \mathrm{D}$ ordination. Analyses were carried out with the R statistical environment and the packages vegan (Oksanen et al., 2012), ade4 (Dray and Dufour, 2007), as well as with custom R scripts. Operational taxonomic units at $98 \%$ sequence identity $\left(\mathrm{OTU}_{0.02}\right)$ that occurred only once in the whole dataset were termed absolute single sequence OTUs ( $\mathrm{SSO}_{\mathrm{abs}}$; Gobet et al., 2012). OTU $\mathrm{U}_{0.02}$ sequences that occurred only once in at least one sample, but may occur more often in other samples were termed relative single sequence OTUs ( $\mathrm{SSO}_{\text {rel }}$; Gobet et al., 2012). $\mathrm{SSO}_{\mathrm{rel}}$ comprise rare organisms that might become abundant when conditions change.

\subsection{Phylogenetic tree calculation}

Phylogenetic analysis was done using the software package ARB (Ludwig et al., 2004) based on the non-redundant ARB SILVA database release 115 (July 2013; Quast et al., 2013). The Flavobacteriaceae $16 \mathrm{~S}$ rRNA phylogenetic tree was calculated by neighborjoining and maximum-likelihood (RAxML and PhyML) analysis with a filter considering only those positions that are conserved in at least $50 \%$ of the selected sequences ( 1270 positions in total). For tree calculation, only nearly full-length sequences were considered. Unstable branching orders are visualized as a multifurcation. The NOR5/OM60 tree was calculated by PhyML analysis using 100 bootstrap replicates. For each NOR5/OM60 OTU retrieved from our sediments, the longest sequence was selected as a representative (minimum length $>300$ bases, average 400-500 bases) and added to the calculated bootstrap tree under parsimony criteria without allowing changes in the overall tree topology (Peplies et al., 2008). Bootstrap values cannot be shown for added partial sequences.

\subsection{Nucleotide sequence accession numbers}

Pyrotag sequencing raw data have been stored in the sequence read archive under SRA accession number SRP040789.

\subsection{Catalyzed reporter deposition fluorescence in situ hybridization (CARD-FISH) and cell enumeration}

The formaldehyde-fixed sediment samples were diluted, ultrasonicated at 20\% intensity, 20 cycles, 20 s (Bandelin, Sonopuls HD 200 ) and filtered on a $0.22 \mu \mathrm{m}$ polycarbonate filter. Total microbial cell numbers were determined using the nucleic acid stain DAPI $(1 \mu \mathrm{g} / \mathrm{ml})$. CARD-FISH was performed as previously described (Ishii et al., 2004) with the following modifications. For detection of Archaea, cell walls were permeabilized with 0.5\% SDS (Sigma, Germany) for $10 \mathrm{~min}$ at room temperature. For detection of Bacteria, Flavobacteria, and NOR5/OM60, cell walls were permeabilized with lysozyme $(1000 \mathrm{kU} / \mathrm{ml})$ for $45 \mathrm{~min}$ at $37^{\circ} \mathrm{C}$. Cells were embedded in mounting medium and counted in 50-100 independent microscopic fields of view using a Nikon Eclipse 50i epifluorescence microscope or a Zeiss Axioskop 2 MOT plus. A complete list of probes used in this study is provided in the Supplementary material (Table S1). Images were taken by confocal laser scanning microscopy (LSM780, Zeiss).

\section{Results}

\subsection{Description of the sampling sites, pelagic settling particles and sediments}

We investigated the top sediment layers $(0-5 \mathrm{~cm})$ of five stations along the Antarctic Polar Front (Fig. 1 and Table 1). The sediments collected at the abyssal stations (81-175) were retrieved at a water depth between 3760 and $4154 \mathrm{~m}$ and had different exposure times to bloom-derived particles at the time of sampling. In the following we use a sample ID indicating the bloom, station and exposure time to particulate organic carbon (POC; e.g. A81 $1_{\text {short }}$ - A: bloom A; 81: station 81; short: short exposure to $\mathrm{POC}$ ). Station R177 was a shallow reference site (340 m) located on the continental shelf. The upper layers of all abyssal sediments were well oxygenated (Wolf-Gladrow, 2013).

Using Level-3 Aqua MODIS chlorophyll satellite images (a combination of 3- and 8-days composite of $4 \mathrm{~km}$ resolution in HDF format) from NASA GSFC (http://oceancolor.gsfc.nasa.gov), we followed the surface phytoplankton development in $100 \mathrm{~km}^{2}$ grids above each of the 5 stations from early December 2011 to early April 2012. We observed a short phytoplankton bloom at site A81 $1_{\text {short }}$, which began in mid-December 2011, had peak values of $2-3 \mathrm{mg}$ Chla m $\mathrm{m}^{-3}$ and declined again to $\sim 1 \mathrm{mg} \mathrm{Chla} \mathrm{m}^{-3}$ by mid of January, giving similar values as the measured surface Chla concentration at station 81 (Table 1). The Chla concentration in this region remained constantly low during the rest of the cruise, indicating a typical after-bloom situation with a developed zooplankton community. Supporting this, we measured a relatively low concentration of $10 \mathrm{~g} \mathrm{~m}^{-2}$ POC (integrated over the upper $150 \mathrm{~m}$ water column; Table 1) and observed large numbers of diatom shells in both top sediment layers and even down to $5 \mathrm{~cm}$ depth as well as fecal pellets produced by pelagic calanoid copepods and euphasiids (Fig. S1). Drifting sediment traps deployed at $300 \mathrm{~m}$ depth (01-21-2012) showed very high contribution from similar fecal pellets to the total settling material.

In addition, we sampled sediments during (B86 short $_{\text {, }}$ 02-01-2012) and at the end (B141 long, 02-19-2012) of a large-scale and extended open ocean phytoplankton bloom which had peak values of $\sim 3 \mathrm{mg}$ Chla $\mathrm{m}^{-3}$ from mid-December until our first sampling in early February. During February, the surface Chla values declined to $<1 \mathrm{mg} \mathrm{m}^{-3}$ and further to values $<0.5 \mathrm{mg} \mathrm{m}^{-3}$ by the end of March. At B86 $6_{\text {short }}$ the integrated POC concentration in the upper $150 \mathrm{~m}$ water column was high ( $32 \mathrm{~g} \mathrm{~m}^{-2}$, Table 1$)$, but we did not observe any clear differences between the two sediment layers, 
which both consisted of unidentified organic matter, possibly heavily fragmented and degraded fecal pellets and broken, empty diatoms, which indicate zooplankton grazing (Fig. S2). This suggested that the major transport mechanism of POC to the sediments was in the form of fecal pellets. Three weeks later the integrated concentration of $\mathrm{POC}$ had decreased to $25 \mathrm{~g} \mathrm{~m}^{-2}$ (Table 1 ) in the surface waters. The sediment layer 2 looked very similar to the sediment collected three weeks earlier, while sediment layer 1 differed by the presence of fresh looking copepod and euphasiid fecal pellet fragments (Fig. S3). Additionally, we found a larger number of diatoms at B141 long as compared to B86 $6_{\text {short, }}$ which suggested that a pulse of organic matter had reached the seafloor. Between sampling of B86 $6_{\text {short }}$ and $B 141_{\text {long }}$ we followed the composition of settling material collected at $300 \mathrm{~m}$ water depth in daily intervals and observed a peak in fecal pellet export between the 6th and 8th of February. This coincided with a general decrease in Chla concentration estimated from satellite images and suggested that a shift in the pelagic food structure had occurred, seemingly caused by an increase in zooplankton grazing and fecal pellet production. This shift may have caused the rapid transport of material from the surface ocean to the abyssal seafloor, which is supported by the presence of fresh looking fragments of fecal pellets and autofluorescent cell material.

Station C175 1 long (03-04-2012), north of South Georgia, was characterized by very high Chla concentrations observed in the satellite images already from the beginning of December until mid-January with values exceeding $4 \mathrm{mg}$ Chl $\mathrm{m} \mathrm{m}^{-3}$. However, from mid-January the Chla concentration started to decrease and

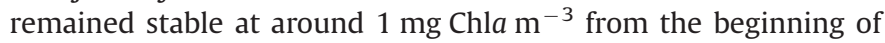
February until our sampling in early March, when integrated POC concentrations were relatively low at $13 \mathrm{~g} \mathrm{~m}^{-2}$ (Table 1). The microscopic observations of the sediment samples showed that layer 1 had more unidentified organic matter than layer 2 and contained large diatoms, which suggests that some recent export event must have taken place (Fig. S4). Diatoms were found in up to $3 \mathrm{~cm}$ sediment depth and again most of them were broken, indicating a high degree of grazing by zooplankton and thus likely export in the form of rapidly sinking fecal pellets (Fig. S5). We observed autofluorescence signals in the organic fraction of the surface sediment, suggesting a relatively fast transport from the surface ocean to the $4150 \mathrm{~m}$ deep sediment. Drifting traps were deployed at 300 m water depth (03-02-2012) and collected material indicating that salps, large calanoid copepods and euphasiids were producing fast sinking pellets at high rates. The sediment at the reference site R177 contained almost no diatom shells, but large amounts of fine organic matter. The surface Chla at this coastal site had values between $\sim 5 \mathrm{mg} \mathrm{m}^{-3}$ in early December 2011 and $\sim 1 \mathrm{mg} \mathrm{m}^{-3}$ in mid-March.

\subsection{Bacterial community structure}

The main objective of this study was to unravel a possible influence of a phytoplankton bloom on the benthic bacterial community structure in Southern Atlantic ocean abyssal sediments. Thus, we were interested not in archiving the present bacteria but in identifying the active members of the bacterial community. As changes in the structure of a community become more rapidly visible in the metatranscriptome than in the metagenome our target molecule was the 16S rRNA instead of its corresponding gene. This approach allowed us not only to distinguish between active and inactive or dead and alive bacterial cells but also prevented the detection of bacteria based on free DNA.

By 454 pyrosequencing we obtained 119,766 quality-controlled partial 16S rRNA sequences after a rigorous bioinformatics routine. The sequencing data presented here have not been used in a quantitative way to identify dominant populations at the five sites but, as RNA extraction, cDNA synthesis, PCR, and sequencing have been done in parallel for all samples, relative sequence abundance of specific bacterial clades have been used to identify shifts between the sampling sites.

\subsection{Diversity of active microbial communities in abyssal sediments}

We analyzed the diversity of active microbial communities that were present in the top two layers of the sediment (layer 1: 0-1 cm; layer 2: $1-2 \mathrm{~cm}$ ). Within the obtained 119,766 quality-controlled 16S rRNA sequences we identified 12,297 operational taxonomic units at $98 \%$ sequence identity $\left(\mathrm{OTU}_{0.02}\right)$. The final length of the processed amplicons was homogeneous as both mean and median length was $245 \mathrm{bp}$ (range: 219-286 bp). On average we observed $2205 \mathrm{OTU}_{0.02}$ per sample, of which $60 \%$ were absolute single sequence OTUs $\left(\mathrm{SSO}_{\mathrm{abs}}\right)$ that occurred only once in the whole dataset. In addition, each sample contained on average $60 \%$ relative single sequence OTUs ( $\mathrm{SSO}_{\text {rel }}$ ), which are OTUs that occur only once in a given sample, but are more abundant in other samples (Gobet et al., 2012). To compare the samples we subsampled the datasets to correct for the unequal sampling effort. After subsampling, the number of observed and estimated $\mathrm{OTU}_{0.02}$ was similar at all stations with an average of 756 and $2202 \mathrm{OTU}_{0.02}$, respectively. Exceptions were layer 1 of the reference R177, which had a higher,

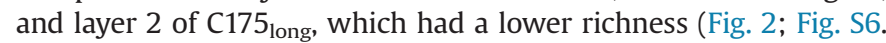
Table S2). The evenness $(D)$ of the communities was calculated using the Inverse Simpson diversity index. Evenness was high in most of the cases ranging from 122 to 283 , peaking at layer 1 of the reference site, followed by layer 1 at $A 81_{\text {short }}(D=247)$. However, layer 1 at station $\mathrm{B} 141_{\text {long }}(D=51)$ and both top layers at station C175 long $(D=17$ and $D=38$ ), which were the sites with long exposure to POC, had a much lower evenness (deviating more than one standard deviation of the mean evenness; Fig. 2).

\subsection{Bacterial community turnover}

We visualized the community structure based on OTU $_{0.02}$ using non-metric multidimensional scaling. Both sediment layers at the stations with short exposure to POC (A81 $1_{\text {short }}$ and B86 $6_{\text {short }}$ ) were very similar to each other, whereas the two sediment layers at stations with long POC exposure (B141 long and $\mathrm{C} 175_{\text {long }}$ ) as well as the coastal station R177 were very different (Fig. 3). Interestingly, layer 1 of both stations with long exposure to phytoplankton was very similar, although layer 2 of these stations showed major differences, indicating that a shift towards similar active organisms occurred in the topmost layer at both stations. On average, the active communities shared $15 \%$ of $\mathrm{OTU}_{0.02}$ among each other, ranging from as little as $4 \%$ to a maximum of $42 \%$ shared $\mathrm{OTU}_{0.02}$ between any two samples.

\subsection{Bacterial community composition}

To investigate which clades might be responsible for the observed community shifts we looked at relative abundances of partial 16S rRNA sequences. In total, we detected 42 bacterial phyla in the ten investigated sediment layers and each sample contained on average $28 \pm 7$ phyla. The twelve phyla that were found at all sites and layers (Table S3) were also those with the highest relative sequence abundances. Despite the diversity among the rare phyla each site seemed to be greatly dominated by Proteobacteria, which had an average relative sequence abundance of $64 \pm 11 \%$.

The diversity at a finer phylogenetic resolution was unexpectedly high, since we found in total 365 clades on family level. The 40 most abundant clades (Fig. 4), encompass between $69 \%$ and 
(A)



(B)

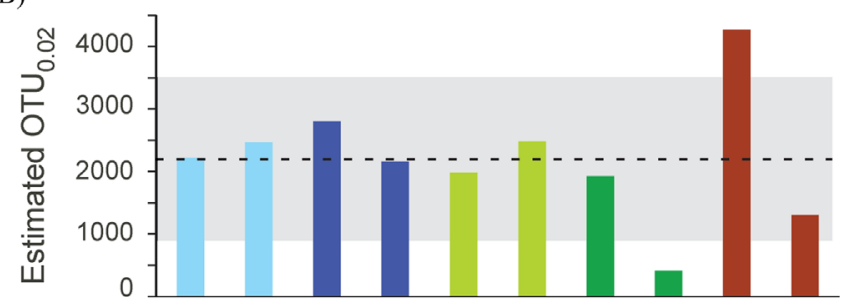

(C)

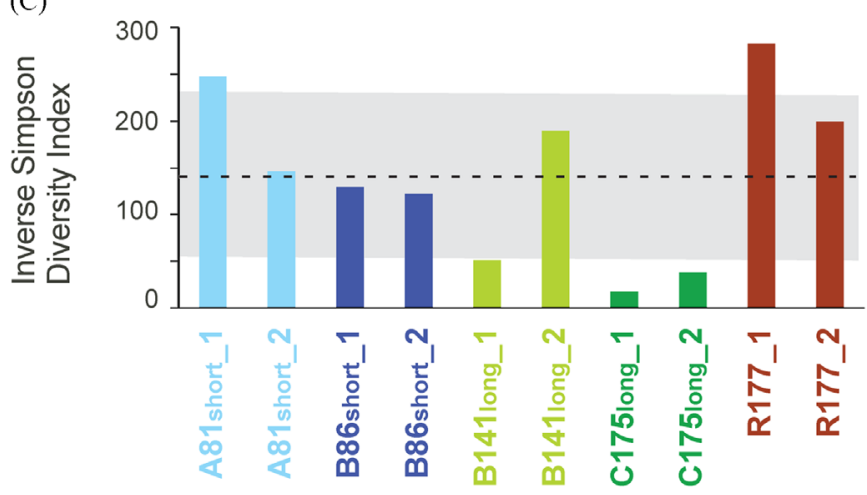

Sediment samples

Fig. 2. Microbial diversity in Antarctic Polar Front sediments. Observed (A) and estimated (B) bacterial OTU $_{0.02}$ (operational taxonomic unit at 98\% 16S rRNA sequence identity) richness and Inverse Simpson diversity indices (C), of the two top layers at each station based on subsampling of 2000 16S rRNA sequences. The dashed line represents the mean over all samples and the gray area depicts one standard deviation of the mean.

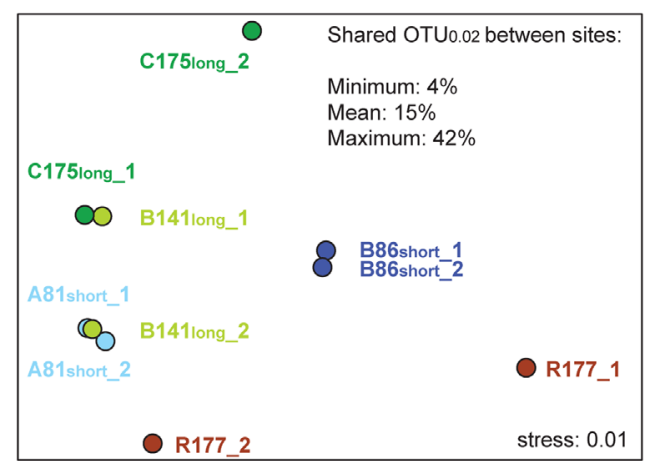

Fig. 3. Non-metric multidimensional scaling of microbial community structure. The ordination is based on the relative abundance of $\mathrm{OTU}_{0.02}$ (Bray-Curtis dissimilarity). The values for shared $\mathrm{OTU}_{0.02}$ between sites are based on presence/absence (Jaccard dissimilarity) and show that overall the samples were quite similar to each other.

$82 \%$ of $\mathrm{OTU}_{0.02}$ of a given sample, the rest belonged to a large number of rare clades. In general, the samples were very similar concerning family-level clades, with the alphaproteobacterial Rhodospirillaceae and Rhodobacteraceae and the gammaproteobacterial NOR5/OM60 clade and Sinobacteraceae being the most common. Within those families there were clades that were

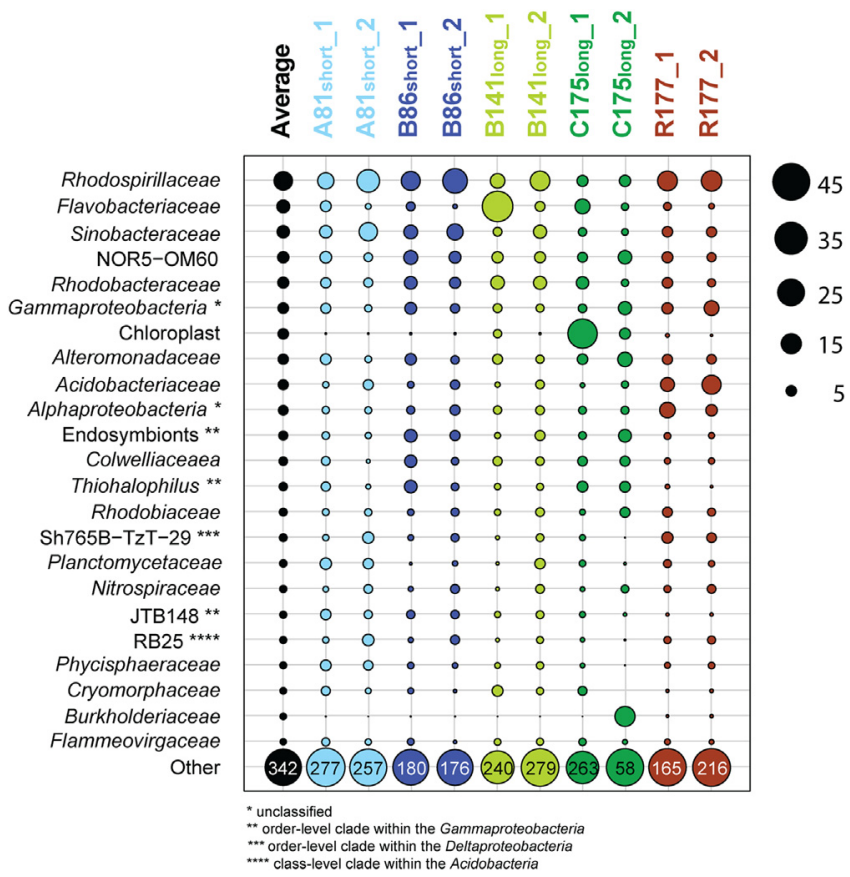

Fig. 4. Relative sequence abundance of $16 \mathrm{~S}$ rRNAs (in percent) and their phylogenetic affiliation, depicted at a resolution of family-level or lower, as classified by ARB SILVA. An exception is NOR5/OM60 that we here show as a separate clade nonconforming with SILVA taxonomy, where it is still assigned to Alteromonadaceae. The clades are listed according to their average relative abundance across all samples (first column). All the listed clades occurred in all samples except the Cryomorphaceae which was missing in sample C175 1 ong_2. Clades that occurred at an average relative abundance of less than $1 \%$ were summed up and listed as "Other". The number represents the amount of rare clades below $1 \%$ relative abundance in the respective sample, a complete list of these clades is given in Table S4.

ubiquitous, diverse and had high relative sequence abundances, most notably related to the genera Pelagibius (Rhodospirillaceae) (mean $\left.=4.2 \% ; \mathrm{SD}=2.3 \% ; 274 \mathrm{OTU}_{0.02}\right)$ and Haliea/Congregibacter (NOR5/OM60) $\left(\right.$ mean $=3.6 \%$; $\mathrm{SD}=1.1 \% ; 90 \mathrm{OTU}_{0.02}$; Fig. $5 \mathrm{~A}$ ) and to a genus-level clade in some studies termed "Marine Benthic Group" (Sinobacteraceae; mean $=4.3 \%$; $\mathrm{SD}=2.6 \% ; 211 \mathrm{OTU}_{0.02}$ ). Within these clades the majority of reads belonged to a few $\mathrm{OTU}_{0.02}$ that we found at all investigated sediments. Remarkably, most sequences affiliated with NOR5/OM60 fell into a distinct cluster that comprised only sequences from marine sediments, indicating the presence of a specialized benthic community in these abyssal ecosystems. However, despite the similarities there were two conspicuous samples, which differed from the others due to an increase of chloroplast ( $\mathrm{C} 175_{\text {long, }}$ layer 1$)$ or Flavobacteriaceae sequences (B141 long, layer 1). The increase of Flavobacteriaceae sequences seemed to be mainly caused by one $\mathrm{OTU}_{0.02}$ related to the genus Psychroserpens, which went from less than $0.1 \%$ relative sequence abundance in layer 1 of B86 $6_{\text {short }}$ to $9.7 \%$ in

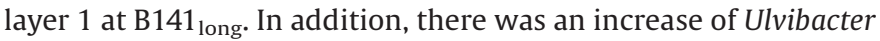
sp. sequences from $0.5 \%$ to $3.3 \%$ caused by two $\mathrm{OTU}_{0.02}$ and also an increase of five unclassified Flavobacteriaceae $\mathrm{OTU}_{0.02}$ from $0.9 \%$ to $10 \%$ (Fig. S7). The peak in chloroplast sequences (station $\mathrm{C} 175_{\text {long }}$ ) was also caused by a single $\mathrm{OTU}_{0.02}$ which was responsible for almost $25 \%$ of all ribosomal sequences that were found at that site. This OTU was $98-99 \%$ similar to sequences of diatoms of the genus Chaetoceros.

\subsection{Abundance and distribution of microorganisms and key bacterial clades}

To visualize and quantify the microorganisms, we used CARDFISH and epifluorescence microscopy. The total microbial cell 



1 OTU (86: $1 / 6$ )
8 OTUs (81: 2/57; 86: 2/26; 141: 3/105; 175: 5/120)
6 OTUs (86: 1/1; 141:3/10; 2/9

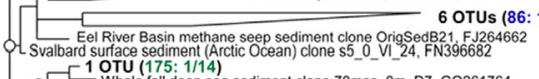

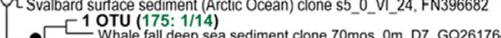

Whale fall deep sea sediment clone $70 \mathrm{mos} 0 \mathrm{~m}$ D D7, GQ261764
New Zealand cold seep clone NZ_309_Bac73, JF268404

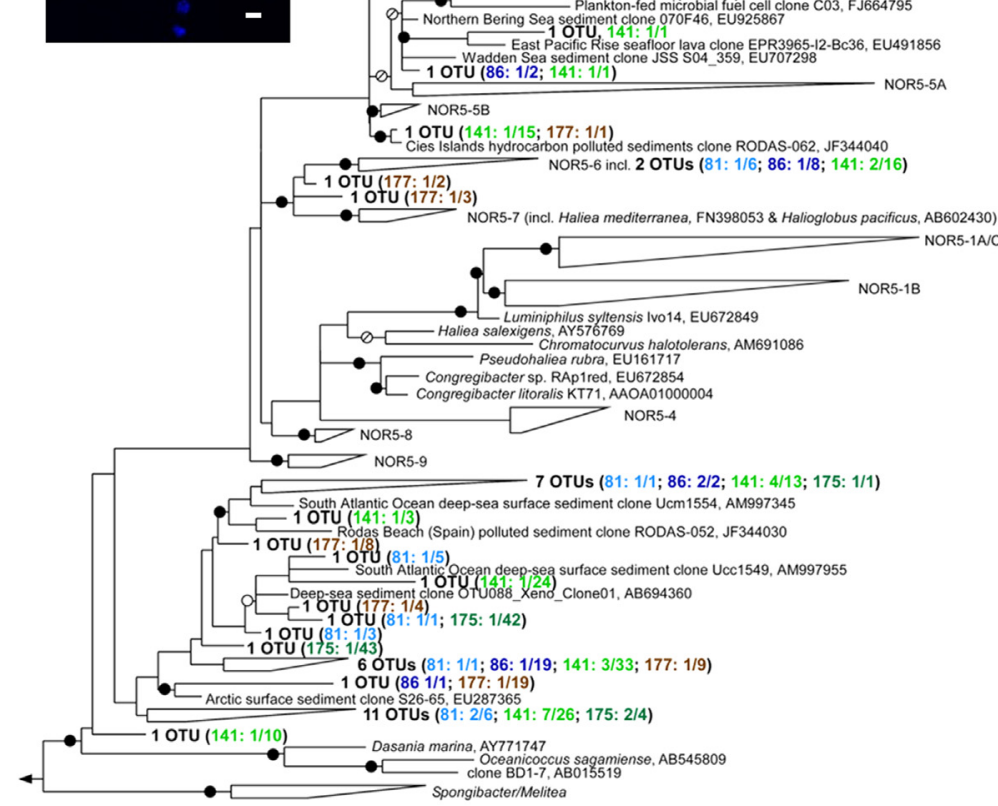

4 OTUs (81: 1/16; 141:1/1; 177: 2/2) ${ }^{14}$ OTUs (81: 2/2; 86: 1/1; 141: 9/9; 177: 2/2) East Pacific Rise seafloor lava clone EPR 3967-02-BC38, EU491786 1 OTU (175: 1/5, 177) 11) Serman Wadden Sea intertidai sediment clone JSS S04.336.

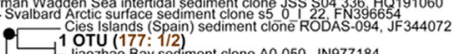
German Wadden Sea intertidal sediments clone JSS SO4 -Pacific Arctic Ocean surface sediment clone S11.58 EU EU287241 516707304 Lucky (141:1/3) - Svalbard Ocean water clone b25. EU919765 1 OTU (81: (1/39)

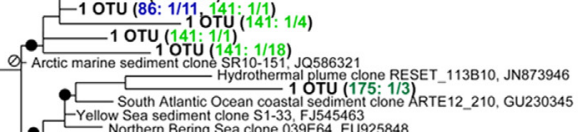

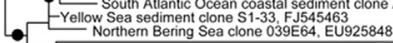
13 OTUs (81:5/5; 86: 3/3; 141: 3/3; 175: 3/49) 2 OTUs (141: 2/2)

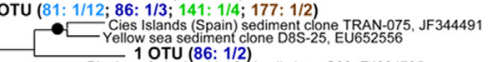

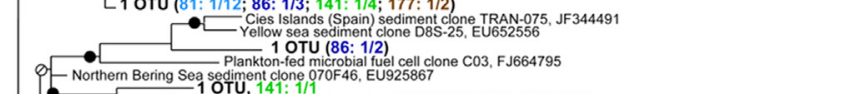
Wadden Sea sediment clone JSS S04_359, EU707298
1 OTU (86: 1/2; 141:1/1) - 1 OTU (141: $1 / 15 ; 177: 1 / 1)$

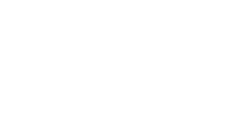

$10 \%$

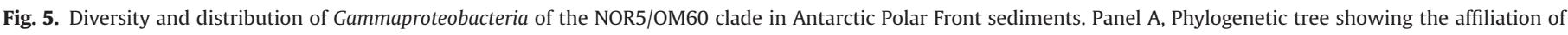

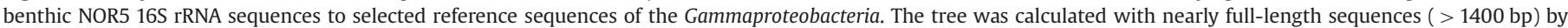



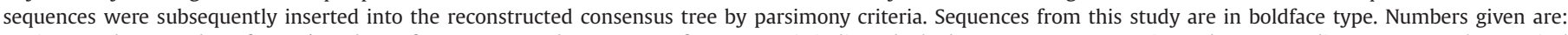

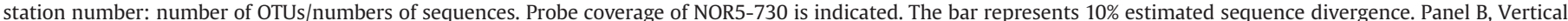

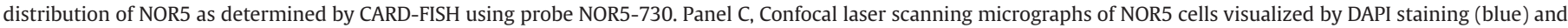
CARD-FISH with probe NOR5-730. Scale bar $=2 \mu \mathrm{m}$.

numbers decreased with depth and were similar at all abyssal stations being on average $6.8 \pm 1.1 \times 10^{8}$ cells $\mathrm{ml}^{-1}$ sediment (layer 1), $\quad 6.4 \pm 0.6 \times 10^{8}$ cells ml $^{-1} \quad$ (layer 2), $\quad 4.6 \pm 0.5 \times$ $10^{8}$ cells $\mathrm{ml}^{-1}$ (layer 3 ) and $3 \pm 0.6 \times 10^{8}$ cells ml $^{-1}$ (layer 4 , Fig. S8). Detection with a general probe mix targeting most Bacteria (probe EUB-338-I-III (Daims et al., 1999) was relatively low compared to other surface sediments (Knittel et al., 2003; Ruff et al., 2013) with $48 \pm 10 \%$ (layer 1), $34 \pm 8 \%$ (layer 2), $39 \pm 19 \%$ (layer 3 ) and $39 \pm 7 \%$ (layer 4). The relative abundance of Archaea (probe ARCH915;Stahl and Amann, 1991) in the abyssal sediments, however, was unexpectedly high with $12 \pm 1 \%$ (layer 1 ), $16 \pm 4 \%$ (layer 2), $13 \pm 3 \%$ (layer 3 ) and $14 \pm 4 \%$ (layer 4; Table S5). 
The high relative sequence abundance of the gammaproteobacterial clade NOR5 was supported by CARD-FISH using probe NOR5-730. At all abyssal sites, NOR5 was detected at average relative cell abundances of $8 \pm 2 \%$ (layer 1 ), $7 \pm 1 \%$ (layer 2 ), $6 \pm 2 \%$ (layer 3 ) and $2 \pm 2 \%$ (layer 4 , Fig. 5B). The cells detected with NOR5-730 were mainly coccoid and of a large cell size with a diameter of 1 to $2 \mu \mathrm{m}$ (Fig. 5C).

The increase of Flavobacteriaceae-related sequences at B $141_{\text {long, }}$ which was indicated by comparative sequence analysis, was also supported by CARD-FISH counts. Here, we detected $0.8 \times$ $10^{8}$ cells $\mathrm{ml}^{-1}$ sediment (15\% of total cell counts) in layer 1 with probe CF319a, targeting most members of the class Flavobacteria (Manz et al., 1996) while only $0.4 \times 10^{8}$ cells $\mathrm{ml}^{-1}$ sediment $(6 \%)$ were found in layer 1 of B86 short. Numerous flavobacterial cells were attached to fecal pellets or other organic particles (Fig. S9), others were free-living.

The shallow reference station was similar to the abyssal sites concerning total cell counts, Bacteria, Archaea and NOR5 (Fig. S8 and Table S5).

\section{Discussion}

\subsection{Export of phytoplankton bloom-derived particulate organic carbon to the seafloor}

The Antarctic Polar Front area of the Southern Atlantic Ocean is a region of high primary productivity and characterized by a large, but sporadic export of organic matter to the deep sea (Sachs et al., 2009). It was shown that benthic foraminiferans contained large amounts of fresh algal pigments at the sites influenced by bloom B and $C$, suggesting a quick transport of algal biomass to the deep sea (Cedhagen et al., 2014). We confirmed that bloom-derived POC indeed reached the seafloor likely within a short period of days to weeks by observing a pulse of organic matter in the form of fecal pellets around February 7th in the area of bloom B. This was further supported by finding fresh fecal pellets produced by copepods, euphasiids and salps as well as fresh diatoms with autofluorescent cell material and 16S rRNA sequences of chloroplasts affiliated to the genus Chaetoceros at the seafloor below bloom C. Especially the presence of intact 16S rRNA is a very strong indicator for fresh, if not viable diatoms, as RNA molecules are generally degraded quickly once the organism is metabolically inactive or dead. Moreover, the presence of intact fecal pellets and chloroplast rRNA at the seafloor provided evidence for a short transport time of few weeks and suggested a strong benthicpelagic coupling due to the export of dense, fast-settling particles. However, this area is influenced by strong currents, eddies and meandering of the frontal system, which might cause lateral transportation of the settling material.

All abyssal regions that we investigated seemed to be strongly influenced by phytoplankton detritus, as we observed thick layers of diatom ooze at each station. We found broken diatom shells and fecal pellets at all stations and sediment layers, indicating a strong influence of zooplankton grazing. However, at station B141 long and C175 1 long, which had a long exposure to phytoplankton bloomderived POC, the top layer of sediment differed from the underlying layers, since we found intact copepod and euphasiid fecal pellets (station B141 long) and fast-settling salp fecal pellets, autofluorescent cell material and large thick-shelled diatoms (station $\mathrm{C} 175_{\text {long }}$ ). Station $\mathrm{C} 175_{\text {long }}$ was in the area north of South Georgia, which is typically characterized by high primary productivity and a large export of biogenic carbon to the deep sea (Jones et al., 2012; Korb et al., 2012). Often fecal pellets contain large amounts of viable and autofluorescent phytoplankton, despite the passage through the gut of a zooplankton organism (Jansen and Bathmann,
2007). Although, both physical and biological factors may decrease sinking velocities (Iversen et al., 2010; Kindler et al., 2010; Macintyre et al., 1995), the presence of these fecal pellets might explain the large amount of organic matter, strong chlorophyll autofluorescence and high relative abundance of chloroplast sequences in layer 1 , but not in layer 2 of station $C 175_{\text {long. }}$.

\subsection{Active microbial communities in abyssal sediments of the Southern Atlantic Ocean}

Although the Antarctic Polar Front in the Atlantic sector is one of the regions with high production and sedimentation in the Southern Ocean, little is known about the benthic microbial communities that make a living of the detritus. Here, we analyzed for the first time the microbial communities that thrive in these sediments using high-throughput sequencing of ribonucleic acid and CARD-FISH. We treated all samples identically and simultaneously to minimize biases, hence although PCR-based results are not quantitative the samples can be compared among each other concerning relative sequence abundances. We sequenced the 16S rRNA molecule for the analysis of microbial diversity as it degrades rapidly and thus can be used to infer active microbial communities. The microbial communities generally showed a high diversity and evenness and were very similar across large spatial distances and different regimes in primary productivity (Longhurst et al., 1995; Sachs et al., 2009). We found ubiquitous sequences of bacterial clades, suggesting that there were benthic populations that are common to these regions of the Southern Ocean and that might be adapted to the environmental conditions and energy sources. The most important clades were alphaproteobacterial Rhodospirillaceae and Rhodobacteraceae as well as gammaproteobacterial "Marine Benthic Group" (Sinobacteraceae) and NOR5/ OM60, the latter was confirmed by CARD-FISH as an abundant clade in situ.

Although the shifts in the ubiquitous clades were not very pronounced it seemed as if some organisms responded to the input of fresh POC, for instance, NOR5, since their average relative sequence abundance and also cell counts were highest at those sites that were affected by a prolonged bloom situation. However, we did not observe large differences in total cell numbers, which indicated that the cells were either actively respiring the material without causing cell division (Witte et al., 2003) or that grazing by meio- and macrofauna in the sediment (Van Oevelen et al., 2006) kept the cell numbers stable. Unfortunately, faunal densities were only available for $\mathrm{A} 81_{\text {short }}$ and B86 $6_{\text {short }}$ (Brandt et al., 2014) where they showed similar values, but not for the sediments that had long exposures to bloom-derived material. It therefore remains elusive whether the stability in microbial cell numbers was accompanied by an increase in faunal biomass. In contrast, incubation experiments showed that microbial communities do respond to phytodetritus pulses by an increase in cell numbers (Turley and Lochte, 1990). Hence the fate of POC in the seafloor still remains largely unknown.

Proteobacteria, especially Gamma-, Delta-, and Alphaproteobacteria are very common members of the bacterial community in coastal (Gobet et al., 2012; Wang et al., 2012) and deep-sea surface sediments (Durbin and Teske, 2011; Liao et al., 2009; Schauer et al., 2010). These clades seemed to be also dominant in the surface sediments along the Antarctic Polar Front. Gammaproteobacteria might be particularly important in Arctic (Bienhold et al., 2011; Ravenschlag et al., 1999) and Antarctic sediments (Carr et al., 2013; Jamieson et al., 2013), which is also indicated by our study. However, the data on key clades in deep-sea sediments is becoming sparser with increasing phylogenetic resolution. We have a quite good understanding of bacterial clades at class level (Zinger et al., 2011), whereas very little is known at family level or higher. 
Organisms affiliated with Sinobacteraceae were found in deep-sea sediments of the central Pacific (Tully and Heidelberg, 2013) and of Scandinavian fjords (Vandieken et al., 2012) and thus might be common to marine sediments. Rhodobacteraceae include many strictly aerobic and often pelagic clades, such as Roseobacter (Buchan et al., 2005; Choi et al., 2007), but they are increasingly found and isolated from coastal (Tian et al., 2009) and deep-sea sediments (Lai et al., 2013; Wang et al., 2009), suggesting that this family is important in many oxic marine realms. However, the Rhodobacteraceae-affiliated organisms that were most abundant in our sequencing dataset could not be classified, indicating that they belonged to novel clades. Rhodospirillaceae-related organisms were also isolated from deep-sea sediments (Lai et al., 2009), however, the clade that seemed to be most abundant along the Antarctic Polar Front, Pelagibius, was to our knowledge only described in seawater samples (Choi et al., 2009). The clade NOR5/OM60 contains Congregibacter litoralis, a marine aerobic, anoxygenic phototroph (Fuchs et al., 2007) and seems to preferably occur in surface waters and coastal sediments with high productivity (Lenk et al., 2011; Spring et al., 2013; Yan et al., 2009). NOR5 sequences have also been repeatedly retrieved from diverse Arctic and Antarctic habitats, e.g. pack ice (Brinkmeyer et al., 2003), sediments (Hubert et al., 2009) and lakes (Glatz et al., 2006). Although we found NOR5 sequences that were closely related to sequences from pelagic samples, the majority clustered among sequences that were retrieved from marine sediments (Hubert et al., 2009; Ruff et al., 2013) (Fig. 5). Deep-sea NOR5 were viable and active as indicated by cell sizes that were comparable to those at surface waters or coastal sediments (Yan et al., 2009). We found NOR5 cell numbers in the abyssal sediment that were at least two orders of magnitude higher than those obtained from surface waters of a phytoplankton bloom in that region (Thiele et al., 2012). Additionally, the presence of high cell numbers in deeper sediment layers suggested that NOR5 are indigenous organisms in these sediments and not just contaminations from surface waters. Our findings indicate that NOR5 are not only relevant in highly productive ocean margins or shelves (Yan et al., 2009), but also in the deep sea of oceanic regions with high surface primary productivity. Hence, they seem to occupy the same ecological niche as their pelagic relatives. We are aware that a certain fraction of the described abyssal populations may originate from the water column, however the presented results strongly support that these clades are adapted to this environment and form persistent communities. In this respect it may even be possible that the organisms originated from the surface, but accumulated, proliferated and diversified in the sediment, establishing a viable community.

\subsection{Benthic community shifts likely caused by algal-derived organic} matter

Although we did not observe major shifts among the bacterial populations that seemed to be ubiquitous and have a high relative abundance, we found two remarkable shifts in the overall microbial diversity. Both top layer sediments that were sampled in the late stage of an extended bloom situation (B141 long and C175 long) had a very low evenness, and were characterized by a high relative sequence abundance of Flavobacteriaceae and chloroplasts, respectively.

The former seemed to be caused by flavobacterial clades that are common to the water column, such as Ulvibacter and Psychroserpens. Ulvibacter was suggested to be involved in the degradation of algal biomass after a phytoplankton bloom in the North Sea (Teeling et al., 2012) and was found in surface waters of the Southern Ocean (Thiele et al., 2012), whereas Psychroserpens was found in marine biofilms (Kwon et al., 2006) and sea-ice (Brinkmeyer et al., 2003). This indicated that these clades might have been transported to the seafloor attached to fecal pellets or diatoms. However, due to the distinct Psychroserpens sequences, which clustered among clones from Pacific (Li et al., 1999) and polar Arctic (Tian et al., 2009) deep-sea sediments (Fig. S7), as well as due to the 100 -fold increase of just one single $\mathrm{OTU}_{0.02}$ we suppose that the Psychroserpens-related organisms were indigenous clades. The same applies to the Ulvibacter-related sequences that we retrieved. They clustered among an organism isolated from the deep-sea and were distinct from the pelagic Ulvibacter, hence are also likely indigenous. Moreover, the cell numbers of Flavobacteria in the sediment were at least two orders of magnitude higher than those found in the water column of that region (Thiele et al., 2012) using the same probe CF319a. These findings together with the cell sizes and rRNA content strongly suggest that the flavobacterial populations were viable.

The peak of chloroplast rRNAs was caused by one $\mathrm{OTU}_{0.02}$ which was classified as Chaetoceros-related. This diatom genus is typical for this region (Sachs et al., 2009), was observed during the cruise in the water column and the settling material, as both marine snow and fecal pellets, and blooms in Antarctic and SubAntarctic waters close to coasts and continental shelves (Smetacek and Naqvi, 2008) or areas with high iron input downstream of land masses (Abelmann et al., 2006) like the region of station C175 1 long. It is known that upon grazing of phytoplankton by zooplankton, chloroplasts can pass through the gut and be excreted without being digested (Jansen and Bathmann, 2007), and thus still contain active ribosomes and intact rRNA. Hence the fast-settling salp fecal pellets that we only observed in the sediment traps at that station might be a possible way of organic matter export to the deep sea. However, another scenario was proposed in which mass mortality and aggregate formation of Chaetoceros spp. would cause a massive pulse to the deep sea in that area (Smetacek et al., 2012), which could also explain the intense peak that we observed. In any case, our results strongly suggested that phytoplankton-derived organic matter and possibly pelagic microorganisms were quickly transported to the deep sea causing a community shift towards bacterial clades that seem to be specialized in the degradation of algal detritus.

To investigate shifts in microbial community structure it would have been ideal to include a reference sample that had not been influenced by phytoplankton blooms. Unfortunately, in the austral summer the entire Southern Ocean is influenced by blooms and in winter sampling campaigns are very rare due to the harsh conditions and ice cover. However, it is remarkable how similar the benthic microbial communities are across a distance of over $4000 \mathrm{~km}$ (Figs. 2-5, S8, and Tables S2-S5). Thus, the observed differences in sequence abundance and cell numbers of certain clades may likely represent relevant shifts of indigenous benthic microbial communities.

\section{Conclusion}

Comparative 16S rRNA sequence analysis and CARD-FISH indicated a dominance of specific clades of Alpha- and Gammaproteobacteria as well as Flavobacteria (periodically) in upper abyssal sediments of oceanic provinces that show a strong benthic-pelagic coupling. Among these benthic clades were many relatives of organisms that degrade algal detritus in surface waters, such as NOR5/OM60, hence Polar Front deep-sea sediments may represent a niche for these organisms that was so far overlooked. The rapidly transported phytoplankton-derived organic carbon seemed to fuel diverse microbial communities, with local input causing changes in community structure. Thus, the degradation of fresh algal biomass 
might be a major source of energy for benthic microbial communities of vast areas of seafloor in high-latitude regions.

\section{Acknowledgments}

We gratefully acknowledge the captain and crew of the German research vessel "Polarstern" for their support during cruise ANT-XXVIII/3. We thank Angelika Brandt for coordination of SYSTCO II benthos work and fruitful discussions, Anke Meyerdierks for help with sequence processing and Catherine Lalande for helpful comments on the manuscript. This study was funded by the Max Planck Society. SER was supported by the Leibniz program of the Deutsche Forschungsgemeinschaft to Antje Boetius.

\section{Appendix A. Supplementary material}

Supplementary data associated with this article can be found in the online version at http://dx.doi.org/10.1016/j.dsr2.2014.05.011.

\section{References}

Abelmann, A., Gersonde, R., Cortese, G., Kuhn, G., Smetacek, V., 2006. Extensive phytoplankton blooms in the Atlantic sector of the glacial Southern Ocean. Paleoceanography 21, PA1013, http://dx.doi.org/10.1029/2005PA001199.

Bienhold, C., Boetius, A., Ramette, A., 2011. The energy-diversity relationship of complex bacterial communities in Arctic deep-sea sediments. ISME J. 6 , 724-732.

Boyd, P., Newton, P., 1995. Evidence of the potential influence of planktonic community structure on the interannual variability of particulate organic carbon flux. Deep-Sea Res. I 42, 619-639.

Boyd, P., Newton, P., 1999. Does planktonic community structure determine downward particulate organic carbon flux in different oceanic provinces? Deep-Sea Res. I 46, 63-91.

Boyd, P.W., Trull, T.W., 2007. Understanding the export of biogenic particles in oceanic waters: is there consensus? Prog. Oceanogr. 72, 276-312.

Brandt, A., Gooday, A.J., Brandao, S.N., Brix, S., Brokeland, W., Cedhagen, T. Choudhury, M., Cornelius, N., Danis, B., De Mesel, I., Diaz, R.J., Gillan, D.C., Ebbe, B., Howe, J.A., Janussen, D., Kaiser, S., Linse, K., Malyutina, M., Pawlowski, J. Raupach, M., Vanreusel, A., 2007. First insights into the biodiversity and biogeography of the Southern Ocean deep sea. Nature 447, 307-311.

Brandt, A., Vanreusel, A., Bracher, A., MarieHoppe, C.J., Lins, L., Meyer-Löbbecke, A Altenburg Soppa, M., Würzberg, L., 2014. Are boundary conditions in surface productivity at the Southern Polar Front reflected in benthic activity? Deep-Sea Res. II 108, 51-59, http://dx.doi.org/10.1016/j.dsr2.2014.09.001.

Bray, J.R., Curtis, J.T., 1957. An ordination of the upland forest communities of Southern Wisconsin. Ecol. Monogr. 27, 326-349.

Brinkmeyer, R., Knittel, K., Jürgens, J., Weyland, H., Amann, R., Helmke, E., 2003. Diversity and structure of bacterial communities in Arctic versus Antarctic pack ice. Appl. Environ. Microbiol. 69, 6610-6619.

Bruland, K.W., Silver, M.W., 1981. Sinking rates of fecal pellets from gelatinous zooplankton (Salps, Pteropods, Doliolids). Mar. Biol. 63, 295-300.

Buchan, A., González, J.M., Moran, M.A., 2005. Overview of the marine Roseobacter lineage. Appl. Environ. Microbiol. 71, 5665-5677.

Carr, S.A., Vogel, S.W., Dunbar, R.B., Brandes, J., Spear, J.R., Levy, R., Naish, T.R. Powell, R.D., Wakeham, S.G., Mandernack, K.W., 2013. Bacterial abundance and composition in marine sediments beneath the Ross Ice Shelf, Antarctica. Geobiology 11, 377-395.

Cedhagen, T., Cheah, W., Brache, A., Lejzerowicz, F., 2014. Algal pigments in Southern Ocean abyssal foraminiferans indicate pelagobenthic coupling. Deep-Sea Res. II 108, 27-32, http://dx.doi.org/10.1016/j.dsr2.2014.07.017.

Chao, A., 1984. Nonparametric estimation of the number of classes in a population. Scand. J. Stat. 11, 265-270.

Choi, D.H., Cho, J.-C., Lanoil, B.D., Giovannoni, S.J., Cho, B.C., 2007. Maribius salinus gen. nov., sp. nov., isolated from a solar saltern and Maribius pelagius sp. nov. cultured from the Sargasso Sea, belonging to the Roseobacter clade. Int. J. Syst. Evol. Microbiol. 57, 270-275.

Choi, D.H., Hwang, C.Y., Cho, B.C., 2009. Pelagibius litoralis gen. nov., sp. nov., a marine bacterium in the family Rhodospirillaceae isolated from coastal seawater. Int. J. Syst. Evol. Microbiol. 59, 818-823.

Daims, H., Brühl, A., Amann, R., Schleifer, K.H., Wagner, M., 1999. The domainspecific probe EUB338 is insufficient for the detection of all Bacteria: development and evaluation of a more comprehensive probe set. Syst. Appl. Microbiol. 22, 434-444.

Dray, S., Dufour, A.-B., 2007. The ade4 package: implementing the duality diagram for ecologists. J. Stat. Softw. 22, 1-20.

Durbin, A.M., Teske, A., 2011. Microbial diversity and stratification of South Pacific abyssal marine sediments. Environ. Microbiol. 13, 3219-3234.
Edgar, R.C., Haas, B.J., Clemente, J.C., Quince, C., Knight, R., 2011. UCHIME improves sensitivity and speed of chimera detection. Bioinformatics 27, 2194-2200.

Fischer, G., Ratmeyer, V., Wefer, G., 2000. Organic carbon fluxes in the Atlantic and the Southern Ocean: relationship to primary production compiled from satellite radiometer data. Deep-Sea Res. II 47, 1961-1997.

Fuchs, B.M., Spring, S., Teeling, H., Quast, C., Wulf, J., Schattenhofer, M., Yan, S., Ferriera, S., Johnson, J., Glöckner, F.O., Amann, R., 2007. Characterization of a marine gammaproteobacterium capable of aerobic anoxygenic photosynthesis. Proc. Natl. Acad. Sci. USA 104, 2891-2896.

Glatz, R.E., Lepp, P.W., Ward, B.B., Francis, C.A., 2006. Planktonic microbial community composition across steep physical/chemical gradients in permanently icecovered Lake Bonney, Antarctica. Geobiology 4, 53-67.

Gobet, A., Boer, S.I., Huse, S.M., van Beusekom, J.E.E., Quince, C., Sogin, M.L., Boetius, A., Ramette, A., 2012. Diversity and dynamics of rare and of resident bacterial populations in coastal sands. ISME J. 6, 542-553.

Horner-Devine, M.C., Leibold, M.A., Smith, V.H., Bohannan, B.J.M., 2003. Bacterial diversity patterns along a gradient of primary productivity. Ecol. Lett. 6, 613-622.

Hubert, C., Loy, A., Nickel, M., Arnosti, C., Baranyi, C., Brüchert, V., Ferdelman, T., Finster, K., Christensen, F.M., Rosa de Rezende, J., Vandieken, V., Jørgensen, B.B. 2009. A Constant flux of diverse thermophilic bacteria into the cold Arctic seabed. Science 325, 1541-1544.

Ishii, K., Mußmann, M., MacGregor, B.J., Amann, R., 2004. An improved fluorescence in situ hybridization protocol for the identification of bacteria and archaea in marine sediments. FEMS Microbiol. Ecol. 50, 203-213.

Iversen, M.H., Nowald, N., Ploug, H., Jackson, G.A., Fischer, G., 2010. High resolution profiles of vertical particulate organic matter export off Cape Blanc, Mauritania: degradation processes and ballasting effects. Deep-Sea Res. I 57, 771-784.

Jamieson, R.E., Heywood, J.L., Rogers, A.D., Billett, D.S.M., Pearce, D.A., 2013. Bacterial biodiversity in deep-sea sediments from two regions of contrasting surface water productivity near the Crozet Islands, Southern Ocean. Deep-Sea Res. I 75, 67-77.

Jansen, S., Bathmann, U., 2007. Algae viability within copepod faecal pellets: evidence from microscopic examinations. Mar. Ecol. Prog. Ser. 337, 145-153.

Jones, E.M., Bakker, D.C.E., Venables, H.J., Watson, A.J., 2012. Dynamic seasonal cycling of inorganic carbon downstream of South Georgia, Southern Ocean. Deep-Sea Res. I 59-60, 25-35.

Jørgensen, B.B., Boetius, A., 2007. Feast and famine - microbial life in the deep-sea bed. Nat. Rev. Micro 5, 770-781.

Kindler, K. Khalili, A., Stocker, R., 2010. Diffusion-limited retention of porous particles at density interfaces. Proc. Natl. Acad. Sci. USA 107, 22163-22168.

Knap, A., Michaels, A., Close, A., Ducklow, H., Dickson, A., 1996. Protocols for the joint global ocean flux study (JGOFS) core measurements, JGOFS. Reprint of the IOC Manuals and Guides No. 29. UNESCO 1994, p. 170.

Knittel, K., Boetius, A., Lemke, A., Eilers, H., Lochte, K., Pfannkuche, O., Linke, P., Amann, R., 2003. Activity, distribution, and diversity of sulfate reducers and other bacteria in sediments above gas hydrate (Cascadia Margin, Oregon). Geomicrobiol. J. 20, 269-294.

Korb, R.E., Whitehouse, M.J., Ward, P., Gordon, M., Venables, H.J., Poulton, A.J., 2012. Regional and seasonal differences in microplankton biomass, productivity, and structure across the Scotia Sea: implications for the export of biogenic carbon. Deep-Sea Res. II 59-60, 67-77.

Kruskal, J.B., 1964. Nonmetric multidimensional scaling: a numerical method. Psychometrika 29, 115-129.

Kwon, K.K., Lee, S.J., Park, J.H., Ahn, T.-Y., Lee, H.K., 2006. Psychroserpens mesophilus sp. nov., a mesophilic marine bacterium belonging to the family Flavobacteriaceae isolated from a young biofilm. Int. J. Syst. Evol. Microbiol. 56, 1055-1058.

Lai, P.Y., Miao, L., Lee, O.O., Liu, L.-L., Zhou, X.-J., Xu, Y., Al-Suwailem, A., Qian, P.-Y., 2013. Profundibacterium mesophilum gen. nov., sp. nov., a novel member in the family Rhodobacteraceae isolated from deep-sea sediment in the Red Sea, Saudi Arabia. Int. J. Syst. Evol. Microbiol. 63, 1007-1012.

Lai, Q., Yuan, J., Gu, L., Shao, Z., 2009. Marispirillum indicum gen. nov., sp. nov., isolated from a deep-sea environment. Int. J. Syst. Evol. Microbiol. 59, $1278-1281$.

Lenk, S., Arnds, J., Zerjatke, K., Musat, N., Amann, R., Mußmann, M., 2011. Novel groups of Gammaproteobacteria catalyse sulfur oxidation and carbon fixation in a coastal, intertidal sediment. Environ. Microbiol. 13, 758-774.

Levin, L.A., Gage, J.D., 1998. Relationships between oxygen, organic matter and the diversity of bathyal macrofauna. Deep-Sea Res. II 45, 129-163.

Li, L., Kato, C., Horikoshi, K., 1999. Microbial diversity in sediments collected from the deepest cold-seep area, the Japan Trench. Mar. Biotechnol. 1, 391-400.

Liao, L., Xu, X.-W., Wang, C.-S., Zhang, D.-S., Wu, M., 2009. Bacterial and archaeal communities in the surface sediment from the northern slope of the South China Sea. J. Zhejiang Univ. Sci. B 10, 890-901.

Löder, M.G.J., Meunier, C., Wiltshire, K.H., Boersma, M., Aberle, N., 2011. The role of ciliates, heterotrophic dinoflagellates and copepods in structuring spring plankton communities at Helgoland Roads, North Sea. Mar. Biol. 158, 1551-1580.

Longhurst, A., Sathyendranath, S., Platt, T., Caverhill, C., 1995. An estimate of global primary production in the ocean from satellite radiometer data. J. Plankton Res. 17, $1245-1271$.

Ludwig, W., Strunk, O., Westram, R., Richter, L., Meier, H., Yadhukumar, Buchner, A., Lai, T., Steppi, S., Jobb, G., Forster, W., Brettske, I., Gerber, S., Ginhart, A.W., Gross, O., Grumann, S., Hermann, S., Jost, R., Konig, A., Liss, T., Lussmann, R., May, M. Nonhoff, B., Reichel, B., Strehlow, R., Stamatakis, A., Stuckmann, N., Vilbig, A., 
Lenke, D.B.M., Ludwig, T., Bode, A., Schleifer, K.-H., 2004. ARB: a software environment for sequence data. Nucl. Acids Res. 32, 1363-1371.

MacIntyre, S., Alldredge, A.L., Gotschalk, C.C., 1995. Accumulation of marine snow at density discontinuities in the water column. Limnol. Oceanogr. 40, 449-468.

Mann, A.J., Hahnke, R.L., Huang, S., Werner, J., Xing, P., Barbeyron, T., Huettel, B., Stüber, K., Reinhardt, R. Harder, J., Glöckner, F.O., Amann, R.I., Teeling, H., 2013. The genome of the alga-associated marine flavobacterium Formosa agariphila KMM $3901 \mathrm{~T}$ reveals a broad potential for degradation of algal polysaccharides. Appl. Environ. Microbiol. 79, 6813-6822.

Manz, W., Amann, R., Ludwig, W., Vancanneyt, M., Schleifer, K.-H., 1996. Application of a suite of $16 \mathrm{~S}$ rRNA-specific oligonucleotide probes designed to investigate bacteria of the phylum cytophaga-flavobacter-bacteroides in the natural environment. Microbiol 142, 1097-1106.

Meyerdierks, A., Kube, M., Kostadinov, I., Teeling, H., Glöckner, F.O., Reinhardt, R., Amann, R., 2010. Metagenome and mRNA expression analyses of anaerobic methanotrophic archaea of the ANME-1 group. Environ. Microbiol. 12, 422-439.

Moodley, L., Middelburg, J.J., Boschker, H.T.S., Duineveld, G.C.A., Pel, R., Herman, P. M.J., Heip, C.H.R., 2002. Bacteria and Foraminifera: key players in a short term deep-sea benthic response to phytodetritus. Mar. Ecol. Prog. Ser. 236, 23-29.

Muyzer, G., Teske, A., Wirsen, C.O., Jannasch, H.W., 1995. Phylogenetic relationships of Thiomicrospira species and their identification in deep-sea hydrothermal vent samples by denaturing gradient gel electrophoresis of 16S rDNA fragments. Arch. Microbiol. 164, 165-172.

Oksanen, J., Blanchet, F.G., Kindt, R., Legendre, P., Minchin, P.R., O`Hara, R.B., Simpson, G.L., Solymos, P., Stevens, M.H.H., Wagner, H., 2012. Vegan: Community Ecology Package.

Peplies, J., Kottmann, R., Ludwig, W., Glöckner, F.O., 2008. A standard operating procedure for phylogenetic inference (SOPPI) using (rRNA) marker genes. Syst. Appl. Microbiol. 31, 251-257.

Pinhassi, J., Sala, M.M., Havskum, H., Peters, F., Guadayol, Ò., Malits, A., Marrasé, C., 2004. Changes in bacterioplankton composition under different phytoplankton regimes. Appl. Environ. Microbiol. 70, 6753-6766.

Ploug, H., Iversen, M., Koski, M., Buitenhuis, E.T., 2008. Production, oxygen respiration rates, and sinking velocity of copepod fecal pellets: direct measurements of ballasting by opal and calcite. Limnol. Oceanogr. 53, 469-476.

Quast, C., Pruesse, E., Yilmaz, P., Gerken, J., Schweer, T., Yarza, P., Peplies, J., Glöckner, F.O., 2013. The SILVA ribosomal RNA gene database project: improved data processing and web-based tools. Nucl. Acids Res. 41, D590-D596.

Ravenschlag, K., Sahm, K., Pernthaler, J., Amann, R., 1999. High bacterial diversity in permanently cold marine sediments. Appl. Environ. Microbiol. 65, 3982-3989.

Ruff, S.E., Arnds, J., Knittel, K., Amann, R., Wegener, G., Ramette, A., Boetius, A., 2013. Microbial communities of deep-sea methane seeps at Hikurangi continental margin (New Zealand). PLoS ONE 8, e72627.

Sachs, O., Sauter, E.J., Schlüter, M., Rutgers van der Loeff, M.M., Jerosch, K., Holby, O., 2009. Benthic organic carbon flux and oxygen penetration reflect different plankton provinces in the Southern Ocean. Deep-Sea Res. I 56, 1319-1335.

Scharek, R., Tupas, L.M., Karl, D.M., 1999. Diatom fluxes to the deep sea in the oligotrophic North Pacific gyre at Station ALOHA. Mar. Ecol. Prog. Ser. 182, 55-67.

Schauer, R., Bienhold, C., Ramette, A., Harder, J., 2010. Bacterial diversity and biogeography in deep-sea surface sediments of the South Atlantic Ocean. ISME J. 4, 159-170.

Schloss, P.D., Westcott, S.L., Ryabin, T., Hall, J.R., Hartmann, M., Hollister, E.B. Lesniewski, R.A., Oakley, B.B., Parks, D.H., Robinson, C.J., Sahl, J.W., Stres, B. Thallinger, G.G., Van Horn, D.J., Weber, C.F., 2009. Introducing mothur: opensource, platform-independent, community-supported software for describing and comparing microbial communities. Appl. Environ. Microbiol. 75, 7537-7541.

Schlüter, M., Sauter, E.J., Schäfer, A., Ritzrau, W., 2000. Spatial budget of organic carbon flux to the seafloor of the northern North Atlantic $\left(60^{\circ} \mathrm{N}-80^{\circ} \mathrm{N}\right)$. Glob. Biogeochem. Cycles 14, 329-340.

Sevastou, K., Lampadariou, N., Polymenakou, P.N., Tselepides, A., 2013. Benthic communities in the deep Mediterranean Sea: exploring microbial and meiofaunal patterns in slope and basin ecosystems. Biogeosciences 10, 4861-4878.
Smetacek, V., Klaas, C., Strass, V.H., Assmy, P., Montresor, M., Cisewski, B., Savoye, N. Webb, A., D'Ovidio, F., Arrieta, J.M., Bathmann, U., Bellerby, R., Berg, G.M., Croot, P., Gonzalez, S., Henjes, J., Herndl, G.J., Hoffmann, L.J., Leach, H., Losch, M., Mills, M.M., Neill, C., Peeken, I., Rottgers, R., Sachs, O., Sauter, E., Schmidt, M.M. Schwarz, J., Terbruggen, A., Wolf-Gladrow, D., 2012. Deep carbon export from a Southern Ocean iron-fertilized diatom bloom. Nature 487, 313-319.

Smetacek, V., Naqvi, S.W.A., 2008. The next generation of iron fertilization experiments in the Southern Ocean. Philos. Trans. R. Soc. A: Math., Phys. Eng. Sci. 366, 3947-3967.

Spring, S., Riedel, T., Sproer, C., Yan, S., Harder, J., Fuchs, B., 2013. Taxonomy and evolution of bacteriochlorophyll a-containing members of the OM60/NOR5 clade of marine gammaproteobacteria: description of Luminiphilus syltensis gen. nov., sp. nov., reclassification of Haliea rubra as Pseudohaliea rubra gen. nov. comb. nov., and emendation of Chromatocurvus halotolerans. BMC Microbiol. 13 118.

Stahl, D.A., Amann, R., 1991. In: Stackebrandt, E., Goodfellow, M. (Eds.), Nucleic Acid Techniques in Bacterial Systematics. John Wiley \& Sons Ltd., Chichester, England, pp. 205-248.

Stahl, D.A., Flesher, B., Mansfield, H.R., Montgomery, L., 1988. Use of phylogenetically based hybridization probes for studies of ruminal microbial ecology. Appl. Environ. Microbiol. 54, 1079-1084.

Teeling, H., Fuchs, B.M., Becher, D., Klockow, C., Gardebrecht, A., Bennke, C.M., Kassabgy, M., Huang, S., Mann, A.J., Waldmann, J., Weber, M., Klindworth, A. Otto, A., Lange, J., Bernhardt, J., Reinsch, C., Hecker, M., Peplies, J., Bockelmann, F. D., Callies, U., Gerdts, G., Wichels, A., Wiltshire, K.H., Glöckner, F.O., Schweder, T., Amann, R., 2012. Substrate-controlled succession of marine bacterioplankton populations induced by a phytoplankton bloom. Science 336, 608-611.

Thiele, S., Fuchs, B.M., Ramaiah, N., Amann, R., 2012. Microbial community response during the iron fertilization experiment LOHAFEX. Appl. Environ. Microbiol. 78, 8803-8812.

Tian, F., Yu, Y., Chen, B., Li, H., Yao, Y.-F., Guo, X.-K., 2009. Bacterial, archaeal and eukaryotic diversity in Arctic sediment as revealed by 16S rRNA and 18S rRNA gene clone libraries analysis. Polar Biol. 32, 93-103.

Tully, B.J., Heidelberg, J.F., 2013. Microbial communities associated with ferromanganese nodules and the surrounding sediments. Front. Microbiol. 161 (4).

Turley, C.M., Lochte, K., 1990. Microbial response to the input of fresh detritus to the deep-sea bed. Palaeogeogr. Palaeoclimat. Palaeoecol. 89, 3-23.

Van Oevelen, D. Middelburg. J. Soetaert, K. Moodley, L, 2006. The fate of bacterial carbon in an intertidal sediment: modeling an in situ isotope tracer experiment. Limnol. Oceanogr. 51, 1302-1314.

Vandieken, V., Pester, M., Finke, N., Hyun, J.-H., Friedrich, M.W., Loy, A., Thamdrup, B., 2012. Three manganese oxide-rich marine sediments harbor similar communities of acetate-oxidizing manganese-reducing bacteria. ISME J. 6, 2078-2090.

Wang, B., Tan, T., Shao, Z., 2009. Roseovarius pacificus sp. nov., isolated from deepsea sediment. Int. J. Syst. Evol. Microbiol. 59, 1116-1121.

Wang, Y., Sheng, H.-F., He, Y., Wu, J.-Y., Jiang, Y.-X., Tam, N.F.-Y., Zhou, H.-W., 2012. Comparison of the levels of bacterial diversity in freshwater, intertidal wetland, and marine sediments by using millions of Illumina tags. Appl. Environ. Microbiol. 78, 8264-8271.

Witte, U., Wenzhöfer, F., Sommer, S., Boetius, A., Heinz, P., Aberle, N., Sand, M., Cremer, A., Abraham, W.R., Jørgensen, B.B., Pfannkuche, O., 2003. in situ experimental evidence of the fate of a phytodetritus pulse at the abyssal sea floor. Nature 424, 763-766.

Wolf-Gladrow, D., 2013. The expedition of the research vessel "polarstern" to the Antarctic in 2012 (ANT-XXVIII/3). In: Bornemann, H. (Ed.), Reports on Polar and Marine Research, p. 191.

Yan, S., Fuchs, B.M., Lenk, S., Harder, J., Wulf, J., Jiao, N.-Z., Amann, R., 2009. Biogeography and phylogeny of the NOR5/OM60 clade of Gammaproteobacteria. Syst. Appl. Microbiol. 32, 124-139.

Zinger, L., Amaral-Zettler, L.A., Fuhrman, JA, Horner-Devine, M.C. Huse, S.M. Welch, D.B.M., Martiny, J.B.H., Sogin, M., Boetius, A., Ramette, A., 2011. Global patterns of bacterial beta-diversity in seafloor and seawater ecosystems. PLoS ONE 6, e24570. 